\%

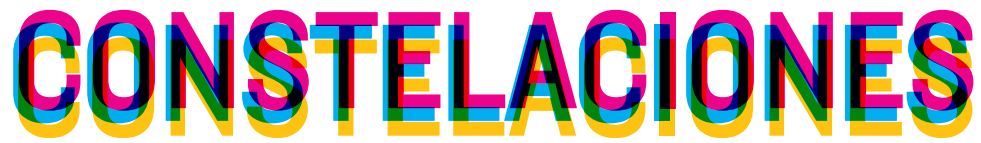

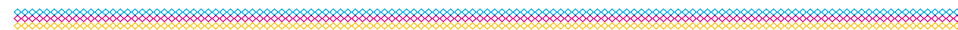


CONSTELACIONES nํㅜ, mayo 2015

Revista de Arquitectura de la Universidad CEU San Pablo

Architecture Magazine of CEU San Pablo University

Periodicidad anual

Annual periodicity

COMITÉ DE REDACCIÓN EDITORIAL COMMITTEE

Dirección Direction

Juan García Millán

Santiago de Molina

Jefa de Redacción Editor in Chief

Covadonga Lorenzo Cueva

Secretario de Redacción Editorial Clerk

Rodrigo Núñez Carrasco

Maquetación y producción Design and production

María Fernández Hernández

Vocales Board Members

Juan Manuel Ros. Escuela Politécnica Superior, Universidad CEU San Pablo, Madrid

Diego Cano Pintos. Escuela Politécnica Superior, Universidad CEU San Pablo, Madrid

Juan Arana Giralt. Escuela Politécnica Superior, Universidad CEU San Pablo, Madrid

Maribel Heredia Castilla. Escuela Politécnica Superior, Universidad CEU San Pablo, Madrid

\section{CONSEJO EDITORIAL EDITORIAL BOARD}

Beatriz Colomina. School of Architecture, Princeton University, New Jersey

Carmen Díez Medina. Escuela de Ingeniería y Arquitectura, Universidad de Zaragoza

María Antonia Frías Sargadoy. Escuela Técnica Superior de Arquitectura, Universidad de Navarra

Juan Miguel Hernández Léon. Escuela Técnica Superior de Arquitectura, Universidad Politécnica de Madrid

Juan José Lahuerta Alsina. Escuela Técnica Superior de Arquitectura, Universidad Politécnica de Cataluña, Barcelona

Eduardo Leira Sánchez. Ex director del Plan General de Ordenación Urbana, Madrid

Joaquín Medina Wamburg. Facultad de Aquitectura Diseño y Urbanismo, Universidad de Buenos Aires

Zaida Muxí Martínez. Escuela Técnica Superior de Arquitectura, Universidad Politécnica de Cataluña, Barcelona

José Joaquín Parra Bañón. Escuela Técnica Superior de Arquitectura, Universidad de Sevilla

Víctor Pérez Escolano. Escuela Técnica Superior de Arquitectura, Universidad de Sevilla

Fernando Pérez Oyarzún. Escuela de Arquitectura y Diseño, Pontificia Universidad Católica, Santiago de Chile

Judith Sheine. School of Architecture and Allied Arts, University of Oregon, Portland

Andrés Walliser Martínez. Global Design, New York University, Nueva York

\section{ISSN 2340-177X}

Depósito legal M-13872-2013

(c) de los textos, sus autores

(c) de las imágenes autorizadas

(c) Revista Constelaciones

๑) Escuela Politécnica Superior, Universidad CEU San Pablo

Universidad CEU San Pablo

Escuela Politécnica Superior

Urbanización Montepríncipe, $s / n$

Boadilla del Monte, 28668. Madrid (España)

constelaciones@eps.ceu.es

www.uspceu.es

Edición Edition

Fundación Universitaria San Pablo CEU

Madrid, España

Impresión Printing

VA Impresores

Impreso en España Printed in Spain

Distribución Distribution

CEU Ediciones

Los textos que componen Constelaciones se obtienen mediante convocatoria pública. Para que los trabajos recibidos entren en el proceso de selección de los artículos a publicar deben ser trabajos originales no publicados anteriormene, con una extensión recomendada de 3.000 palabras, título, resumen (un máximo de 150 palabras) y palabras clave (un mínimo de cuatro palabras), en español y en inglés. Tras haber cumplido estos requisitos (y los correspondientes incluidos en las normas editoriales de la revista, disponibles para consulta en formato digital desde el comienzo de la convocatoria), tiene lugar un proceso de revisión y evaluación de los artículos previa aceptación de los mismos para su publicación. Para acometer dicho proceso, y con el fin de asegurar la calidad de los contenidos, la Revista Constelaciones recurre a evaluadores externos a la institución editora y anónimos (cada artículo es evaluado por dos de ellos) encargados de someter a crítica los mismos. Todos los artículos de investigación publicados en esta revista han pasado por dicho proceso. La recepción de artículos se extendió hasta el 30 de septiembre de 2014. Texts included in Constelaciones are obtained by public announcement. Only original papers that have not been previously published will be included in the process of selection of articles. They should not exceed 3.000 words and should include a title, an abstract (no more than 150 words) and keywords (a minimum of four words), in Spanish and English. After having fulfilled these requirements (and those included in magazine editorial standards, available for consultation from the beginning of the Call for Papers), occurs a process of review and evaluation of articles upon acceptance of them for publication. To undertake this process, and in order to ensure the quality of the contents, Constelaciones turns to external and anonymous evaluators to the institution (each article is evaluated by two of them) responsible for the critic. All the articles published in this journal have undergone this process. The deadline for reception was extended until September 30, 2014.

Todos los derechos reservados. Esta publicación no puede ser reproducida, ni en todo ni en parte, ni registrada, ni transmitida, ni almacenada en ninguna forma ni por ningún medio, sin la autorización previa y por escrito del equipo editorial. En este número se han utilizado algunas imágenes de las que no se ha podido identificar al propietario de los derechos. En estos casos hemos entendido que las imágenes son de libre uso. En caso de identificar alguna de estas imágenes como propia, por favor, póngase en contacto con la redacción de Constelaciones. Los criterios expuestos en los diversos artículos de la revista son responsabilidad exclusiva de sus autores y no reflejan necesariamente los que pueda tener el equipo editoral. El equipo editorial de la revista no se responsabiliza de devolver la información enviada a la redacción a no ser que se le solicite expresamente. All rights reserved. This publication cannot be reproduced, in whole or in part, nor registered, transmitted or stored in any form or by any means, without the written permission of the Editorial team, In this issue some images were used without knowing the owner of the rights. In these cases, we have understood that the images are free of use. In case you identify shared by the editors of this journal. The publisher don't take responsibility for returning submitted material which is not expressly requested. 


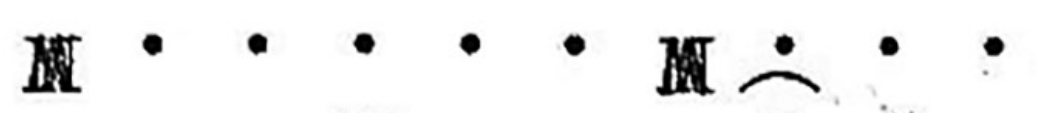

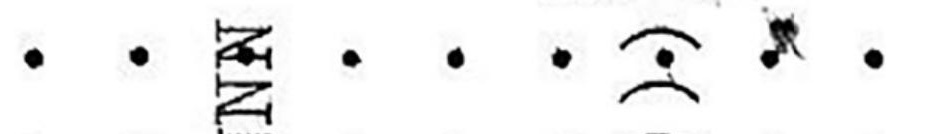

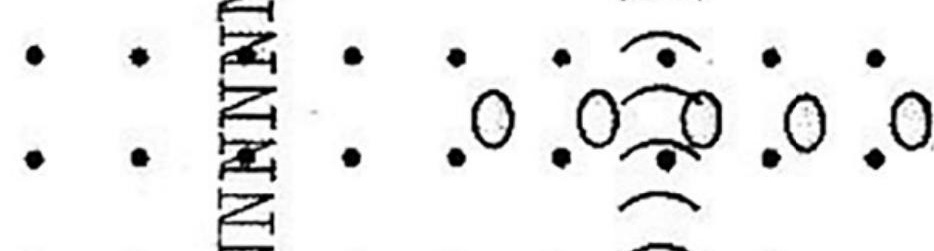

- 0 否 000 a 00

- 0 爱 000 全 00

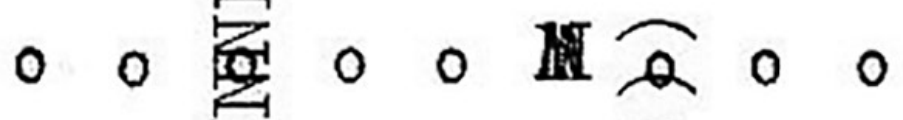

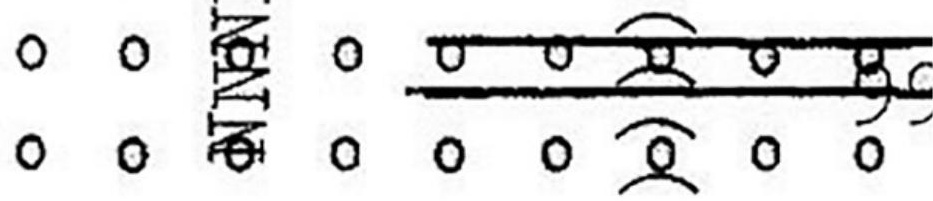

$0 \quad 0 \quad 0 \quad 0 \quad 0 \quad 0$ 2 00

$0 \therefore \therefore \bar{\sigma} 0$ O $0^{\circ}$

$\begin{array}{lllllllll}0 & 0 & 0 & 0 & 0 & 0 & 0 & 0 & 0\end{array}$

M 0 - 0 - 0 - 0 月。

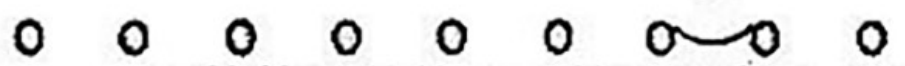

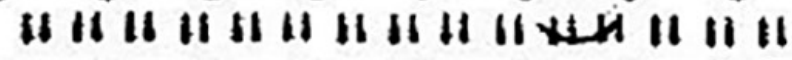

- 0 0 0 o 0 a 00

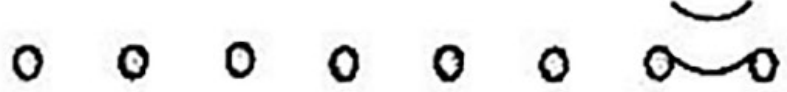

0

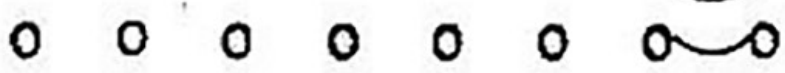

0

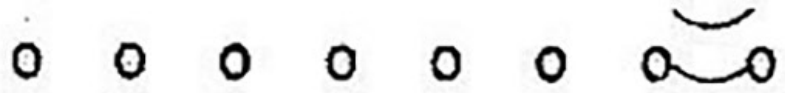

0

政 0 - 0 o 


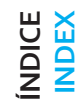

$\hat{m}$

in

요

$\infty$

ֻ̊ำ

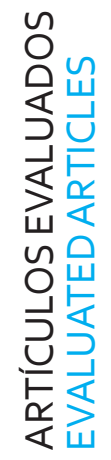
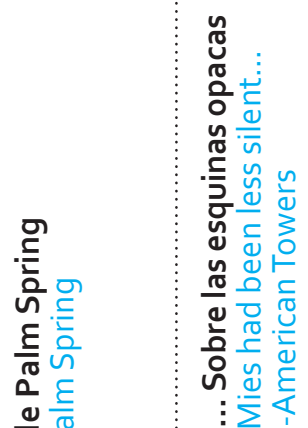

음

o

눈

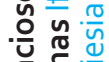

동

要

흥

प⿺辶寸

合 है

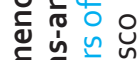

당

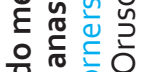

$\sum_{0}$

중

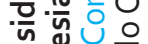

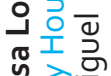

品

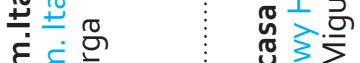

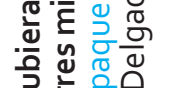

उ.

응

N

๗ั

ज该

ㅂ.

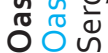

든흥응

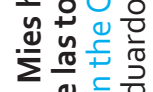

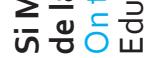

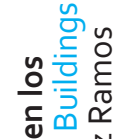

엉 N

른 은

닌

흐 호

는

的㐫

흥

>둥

ํํㅁ 맘

ס)

ปั $\frac{0}{0}$

ชั่ $3 \frac{1}{2}$

ฮ

-

언 $\frac{0}{3} \frac{0}{\pi}$

온

룽

ช

은 을

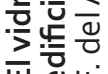

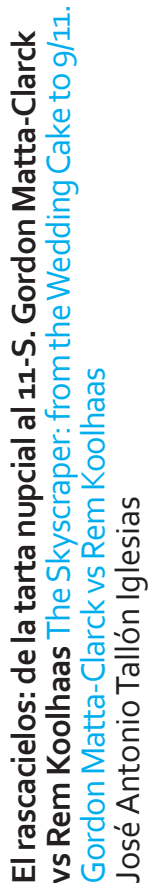

등 응

(

든 $\frac{0}{\pi}$

은 은

-

๘

究

ง

ดั อิ

은

은 ํำ

은 븡

ชั

ติ

든 인

는

ชర

므Nㅗㅇ

드음 궁

으 으 은

c) $\frac{1}{\sigma}$

듬

믄 응

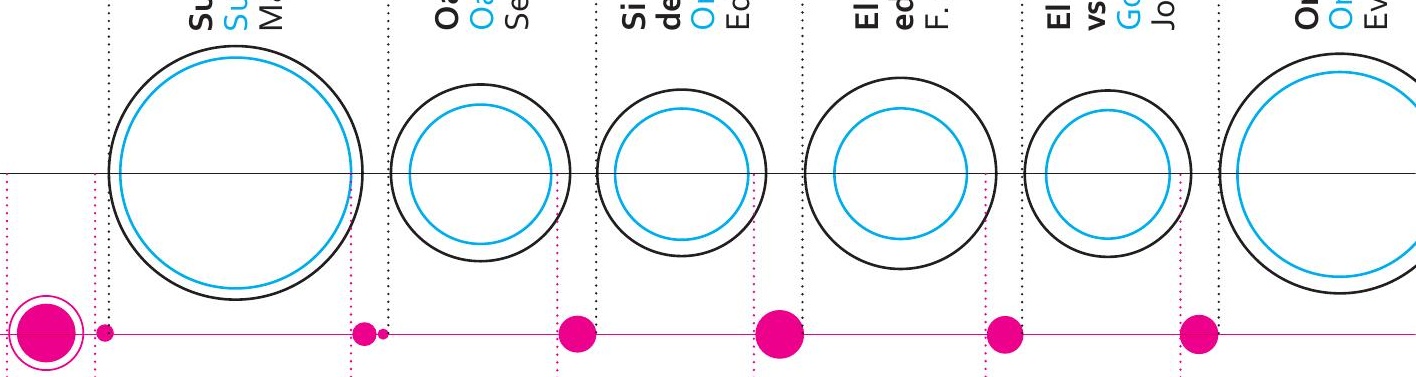

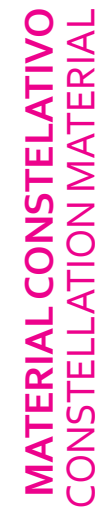

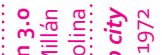

:ํㅡㄴ

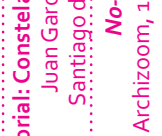

뜸

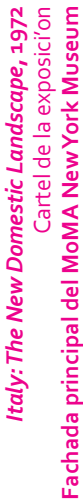

นิ้

앙를

등 ㅎํㅇ

点

융

讨

tูำ

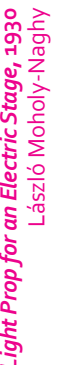

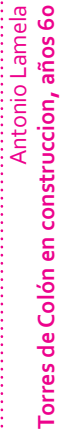

$\underline{\underline{z}} \underline{\underline{a}}=\frac{m}{}$

m

in

ڤ

$\infty$

؛ 


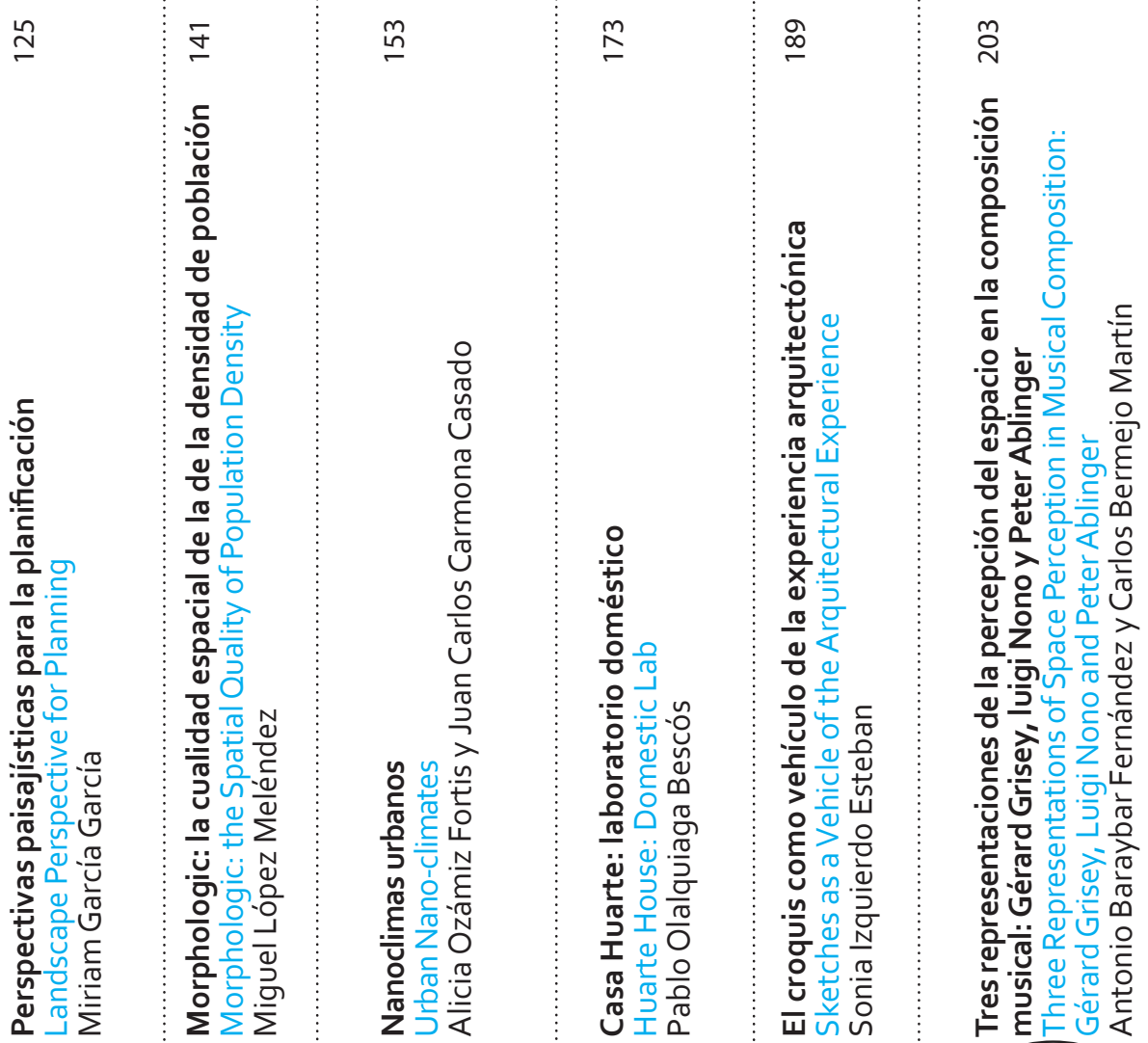




\title{
El rascacielos: de la tarta nupcial al 11-S Gordon Matta-Clarck vs Rem Koolhaas
}

The Skyscraper: from the Wedding Cake to 9/11 Gordon Matta-Clarck vs Rem Koolhaas

\author{
José Antonio Tallón Iglesias \\ Escuela Técnica Superior de Arquitectura, Universidad Politécnica, Madrid \\ Traducción Translation Marta Morán (Iter Translation)
}

\section{Palabras clave Keywords}

Rascacielos, automonumento, anti-monumento, Gordon Matta-Clark, Rem Koolhaas, World Trade Center, eliminación, ausencia Skyscraper, automonument, un-monument, Gordon Matta-Clark, Rem Koolhaas, World Trade Center, elimination, absence

\section{Resumen}

El rascacielos ha sido objeto de controversia desde que fuera engendrado en la incubadora de Manhattan como el nuevo monumento símbolo del poder capitalista. Convertido en una tarta nupcial programática en manos de los promotores, que lo moldean en consonancia con su máxima rentabilidad especulativa, se ha transformado en la extravagante tipología que desea toda nueva metrópolis. Tanto Gordon Matta-Clark como Rem Koolhaas darán rienda suelta a su espíritu crítico arquitectónico no sin cierta ironía, en una década, la de los 70, en la que el World Trade Center inaugura el periodo de decadencia del edificio en altura. Ambos arquitectos propondrán la ausencia como una herramienta crítica con la que recuperar el horizonte perdido de la ciudad, asestando al rascacielos un certero corte que lo transformará proféticamente en un vacío cuya ausencia se convierte súbitamente en la más potente forma de presencia...

\section{Abstract}

The skyscraper has been a controversial typology since it was conceived in the Manhattan incubator as a new monument symbol of the capitalist power. Turned into a programmatic wedding cake into the hands of developers, who mold it in accordance with its maximum speculative profitability, the skyscraper has been transformed into the new bizarre typology that every new metropolis wants to acquire. Both Gordon Matta-Clark and Rem Koolhaas will give free rein to their architectural critical minds - with large amounts of irony - in a decade, the 70's, in which the World Trade Center inaugurates the period of decadence of the skyscraper. Both architects will propose absence as a critical tool to recover the lost horizon of the metropolis, making the right cut to the skyscraper and transforming it into a prophetic void whose absence suddenly become the most powerful form of presence... 
“6. El anti-monumento. Desde la Torre Eiffel todo ha fracasado en la historia de la grandeza moderna, pero esas construcciones provocan satisfacción, ya que se cumplen tres pautas no monumentales. 1_Funciona igual en cualquier tamaño. El souvenir es igual de válido que el original. 2_Es totalmente inservible para la gente. 3_Invita al visitante a alejarse".

"6. The Un-Monument. all has failed since the Eiffel Tower in the history of modern grandeur only it satisfies since it fulfills three non-monumental standars. 1_It is just as good at any size. a souvenir is as good as the real thing. 2_It is totally unfit for people. 3_It invites the visitor to move away".

MATTA-CLARCK, Gordon. (1)

"Es un solipsismo [el del monumento] que exalta tan solo el hecho de su desproporcionada existencia, el descaro de su propio proceso de creación. Este monumento del siglo xx es el automonumento y su manifestación más pura es el rascacielos".

"It is a solipsism [the monument] celebrating only the fact of its disproportionate existence, the shamelessness of its own process of creation. This monument of the 20th century is the Automonument, and its purest manifestation is the Skyscraper".

KOOLHAAS, Rem. (2)

Tras un largo tiempo de frenética actividad constructiva, el skyline irregular de Manhattan se vio definitivamente alterado en la década de los setenta, cuando dos ciclópeas masas grises comenzaron a emerger. En 1973 el World Trade Center ya era una realidad, al igual que la controversia suscitada en torno a la desmesurada irrupción de su silueta en el horizonte de la ciudad. Por aquel año dos relevantes arquitectos coexistirían bajo la sombra de unas torres que, si bien eran la demostración real del éxito del rascacielos como tipología, para ambos representarían el periodo del agotamiento de una monumentalidad mal interpretada.

After a long time of frenetic construction activity, the irregular Manhattan skyline was definitely altered in the seventies, when two cyclopean grey masses began to emerge. In 1973, the World Trade Center was already a reality, as well as the controversy around the disproportionate irruption of its silhouette within the horizon of the city. By that year, two important architects would coexist under the shadow of the two towers that although they were the real demonstration of the success of the skyscraper as typology, for both of them they would represent the period of depletion of a misinterpreted monumentality.

On one hand, Gordon Matta-Clark, through the foundation of the Anarchitecture (3) group the same year, pursued the identification of new spaces that reflected the urban social reality of the times, distancing himself from the speculative circuit. At the same time, a recently arrived Dutch architect, Rem Koolhaas, entered the Institute of Architecture and Urban Studies to start his research on 'manhattanism' under the premises of the Institute. (4) His innovative reflections concerning skyscrapers would be published in 1978, in the retroactive manifesto Delirious New York. The same year, Gordon Matta-Clark died prematurely of an illness, cutting short his brief but promising career. However, in some ways, his reflections found continuity in Rem Koolhaas. Few people apart from Rem Koolhaas (5) had recognised in Gordon Matta-Clark a strong sense of absence that was, in fact, the highest form of presence, a scenario that suddenly converts Rem Koolhaas's thoughts into the involuntary continuator of Matta-Clark's ideas.

For Gordon Matta-Clark, Yamasaki's World Trade Center was the embodiment of "a gigantic rhetoric of excess in both expenditure and production", (6) a symbolic monument to the failure of the American social model. While the city was 
Por un lado, Gordon Matta-Clark que, a través de la fundación del grupo Anarchitecture (3) ese mismo año, perseguiría identificar nuevas categorías de espacios más próximos a la realidad social urbana del momento, alejándose del circuito especulativo. Al mismo tiempo, un recién llegado arquitecto holandés, Rem Koolhaas, ingresaba en el Institute of Architecture and Urban Studies para comenzar su investigación sobre el 'manhattanismo' bajo las premisas del Instituto. (4) Sus singulares reflexiones sobre los rascacielos verían la luz en 1978 bajo la forma del manifiesto retroactivo Delirious New York, el mismo año en el que Gordon Matta-Clark fallece prematuramente víctima de una enfermedad, viendo así truncada su corta aunque prometedora carrera. Y es que, de algún modo, las reflexiones de este último encuentran en Rem Koolhaas una continuidad. Pocos como el propio Rem Koolhaas (5) han sabido reconocer en Gordon Matta-Clark un potente sentido de ausencia como la forma más elevada de presencia, un guión que convierte de súbito el pensamiento de Rem Koolhaas en el involuntario continuador de las ideas del primero.

Para Gordon Matta-Clark, el World Trade Center de Yamasaki es la materialización de "una gigantesca retórica del exceso en gasto y producción", (6) monumento símbolo del fracaso del modelo de sociedad americano. Mientras la ciudad estaba sumida en una crisis alarmante a todos los niveles, (7) el rascacielos se erigía definitivamente como la manifestación más directa del edificio-emblema, representativo de la influencia que ejercen los nuevos regímenes económicos sobre el eje $\mathrm{Z}$ de la ciudad como el verdadero factor de rentabilidad que esconde la realidad social urbana (Fig. 1) Gordon Matta-Clark hará de ello el centro de diversas performances como es el caso del proyecto presentado en el Muelle 18, (8) una zona abandonada adosada al centro financiero. En ella, restituirá el eje $\mathrm{Z}$ ante el impasible telón de fondo de las Torres Gemelas en construcción, un eje paralelo que representa el termómetro capitalista que domina la ciudad y de la que no participa. Una nueva monumentalidad representada por la apoteosis de la materia gris a través del monolito hermético como su envolvente perfecta. (Fig. 2)

immersed in an alarming crisis at all levels, (7) skyscrapers were being continually built. They were the most obvious manifestation of the building-emblem, representing the influence that new economic regimes exercised on the $\mathrm{Z}$ axis of the city, the true profit factor that hid the urban social reality. (Fig. 1) Gordon Matta-Clark made this the centre of his various performances such as the project presented at Pier 18, (8) an abandoned area adjacent to the financial centre. Here he restored the $\mathrm{Z}$ axis against the impassive backdrop of the Twin Towers in construction, a parallel axis that represented the capitalist thermometer that dominated the city and in which he did not participate. It was a new monumentality represented by the apotheosis of the grey substance that perfectly covered the impenetrable monolith. (Fig. 2)

Gordon Matta-Clark regarded the skyscraper as the purest manifestation of an 'un-monument', a mass that encourages people to move away, with no recognisable historic, cultural or social identity, a 'pile of anything. (9) (Fig. 3) As part of an urban grid that was increasingly suffering from the blows of the gradual gentrification (10) process that intensified even more, if possible, the crisis of the 'American Dream'; was not just a speculative matter. The skyscraper is shrouded in a solipsism which isolates it from the urban environment in which it is located, defining its individual character as an indissoluble quality -its reaffirmation as an obelisk, set apart from all context.

Rem Koolhaas regards the skyscraper as an example of a monument to the new ideology, that is being spread silently by the fundamentally private capitalist economic systems, the $¥ € \$$ culture. (11) The architect states that a globalisation process is underway, with origins in the Manhattanism culture and in which the skyscraper is the symbol of the new model 
El rascacielos es, para Gordon Matta-Clark, la manifestación más pura del 'antimonumento', una mole que invita al ciudadano a alejarse, carente de identidad histórica, cultural o social reconocible, un 'montón de nada'. (9) (Fig. 3) Insertado en una retícula urbana que sufre crecientemente los varapalos de un proceso de aburguesamiento (10) progresivo que recrudece aún más si cabe la crisis del sueño americano, no solo se trata de un asunto especulativo. El rascacielos se ve envuelto en un solipsismo que lo aísla del medio urbano en el que se asienta, definiendo su carácter individual como cualidad indisoluble a su reafirmación como obelisco, ajeno a todo contexto.

Para Rem Koolhaas el rascacielos ejemplifica el monumento que celebra la nueva ideología silenciosamente extendida por los sistemas económicos capitalistas de iniciativa primordialmente privada, la cultura del ¥€\$. (11) Según el arquitecto se ha producido un proceso de globalización, con origen en la cultura del manhattanismo, en el cual el rascacielos es el símbolo de la nueva ciudad contemporánea modélica. Es el nuevo 'automonumento': un monolito vacío de contenido que se autoafirma como presencia sin relación con lo que le rodea. Según el arquitecto el World Trade Center se consolida como un enorme monumento a la materia gris que encuentra en la retícula de Manhattan el perfecto laboratorio metropolitano sobre el que testar su éxito. La apoteosis del periodo funcionalista, que comenzó con la construcción del Rockefeller Center durante los años treinta, está marcada según Rem Koolhaas por la construcción de las Torres Gemelas. Su monolitismo es la máxima representación de la automonumentalidad. Cuestión ésta subrayada anteriormente por Gordon Matta-Clark
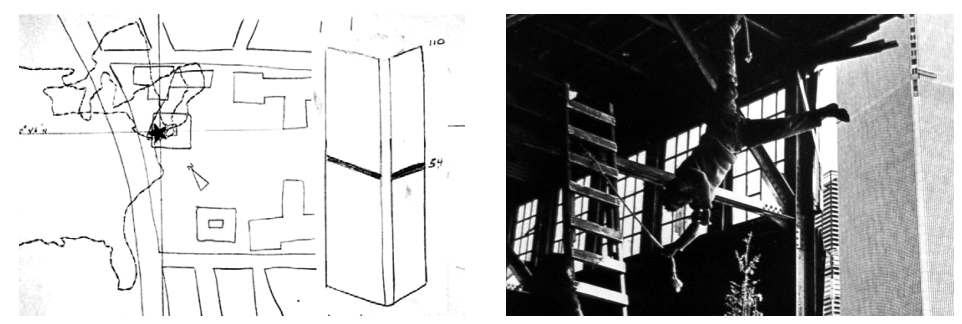

Fig. 1. Matta-Clark, Gordon: USA Map imposed on Urban Map, ca. 1970. Archivo CCA, Montreal [PHCON2002:0016:063]. Collage en el que se identifica el World Trade Center en un plano urbano y un mapa superpuesto, así como un alzado del monolito con el número de plantas.

Fig. 2. Matta-Clark, Gordon. Project: Pier 18, 1971. Gordon Matta-Clark, ante la cámara de Harry Shunk, se suspende de la estructura de la nave alineado sobre un árbol que él mismo planta bajo la mirada congelada de las Torres Gemelas todavía en fase de construcción: la apoteosis de la materia gris. En Shunk, 1992, 76 p.

of a contemporary city. The skyscraper is the new 'automonument': an empty monolith that promotes its own presence without relating to its environment. According to the architect, the World Trade Center establishes itself as an enormous monument to the grey substance he finds in the Manhattan grid, the perfect metropolitan laboratory to test its success. The apotheosis of the functionalism period that began with the construction of the Rockefeller Center in the 1930's is marked by the Twin Towers, according to Rem Koolhaas. Its monolithism is the ultimate representation of automonumentalism. This was also highlighted by Gordon Matta-Clark in his images of Anarchitecture: the towers, which are only original in that there are two of them, interpret the disastrous spectacle of the continuous urban restructuring, a true breakdown of the system. (Fig. 4)

However, it is important to remember how the design of the prototype skyscraper (a product that was later exported to the whole world) was conceived, and the location of that enterprise: Manhattan Island, an excellent gridded laboratory to experiment with the first models.

Rem Koolhaas coined his own 'Skyscraper Theorem' in his retroactive manifesto 'Delirious New York'. Designed at the end of the 19th century, the parameters of the race to conquer the heavens were defined due to two decisive inventions: firstly, the lift in the decade of the 1870's, which allows all horizontal surfaces above the ground floor to be emancipated; and secondly, steel structures in the 1880's, with which it was possible to 'reproduce the world' upwards, indefinitely. Up to this point, the conquest of height was only limited by the structure. (12) 
a través de sus imágenes de Anarchitecture: las torres, cuya única originalidad radica en su apariencia gemelar, interpretan el desastroso espectáculo de la continua reconversión urbana, autentica brecha del sistema. (Fig. 4)

Es importante sin embargo recordar cómo se fraguó el diseño del prototipo de rascacielos -un producto que posteriormente se exportará al resto del mundo- y el lugar donde aconteció tal empresa: la isla de Manhattan por excelencia, el laboratorio reticulado en el que experimentar las primeras enseñanzas.

Rem Koolhaas acuña su propio 'Teorema del Rascacielos' en su manifiesto retroactivo Delirious New York. Diseñado a finales del siglo xIX, se definen las bases de lo que será la carrera por conquistar el cielo gracias a dos factores determinantes: el descubrimiento del ascensor en la década de 1870, con el que se consigue la emancipación de todas las superficies horizontales por encima de la planta baja y, en segundo lugar, la estructura de acero en la década de 1880, gracias a la cual se puede 'reproducir el mundo' indefinidamente en altura. Hasta aquí la conquista de la altura sin más límite que el de su estatura. (12)

Sin embargo, aparecen las primeras restricciones a través de la Ley de Zonificación de 1916, (13) que limita el volumen edificado a una envolvente imaginaria que permita la llegada de luz y aire a las calles de Manhattan. Se definen así las bases de lo que se bautizará como el estilo wedding cake (14) o tarta nupcial, gestado en la ciudad de Nueva York y exportado rápidamente a otras ciudades: todo un cúmulo de setbacks o retranqueos que abren las
Fig. 3. Matta-Clark, Gordon. Anarchitecture (2 piles of rebars), 1974. Archivo CCA, Montreal [PHCON2003:0006:019]. Dos pilas de ferralla apilada, metáfora del World Trade Center como pura acumulación de materia gris sin más cualidades que su apilamiento vertical. Fig. 4. Matta-Clark, Gordon. Anarchitecture, 1974. Archivo CCA, Montreal. Dos cucharas bivalvas de excavación como metáfora del World Trade Center-que se ubica justamente detrás de las mismas - y edl imparable proceso de reconversión urbana.
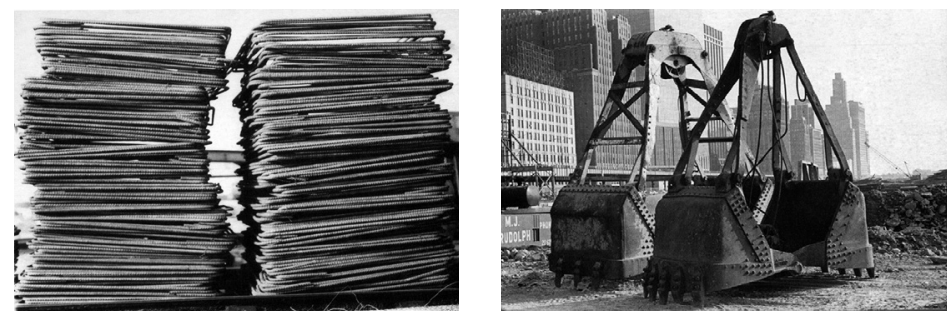

However, the first restrictions appear in 1916 with the Zoning Law (13) that limited the built volume to an imaginary envelope that allowed light and air to be admitted into the Manhattan streets. In this way, the 'wedding cake' style (14) was baptised, hatched in New York and rapidly exported to other cities: an accumulation of setbacks that open the streets to the sky and generated a shape that all architects -subjugated to the developers- ended up designing, with the aim of optimising the profitability of the building. The volume of the building is shaped into what became the prototype of the Manhattan skyscraper-monuments, the wedding cake, characterised by stacking the floors on each other, each one with a smaller area, as if they are the tiers of a wedding cake. As a product of the 1916 Zoning Law, the maximum volume was defined by a pyramid envelope that the developers wanted to get as close to as possible, so they would not lose a millimetre of usable space: due to steel, the mass could be cut into the more conventional rectangular interior spaces as well as lowering the cost of construction. (15) (Fig. 5)

However, paradoxically, and despite the apparent control over built volume, the Law included an exception, so legitimising the icon-skyscraper battle: it authorised the construction of a tower of indefinite height on $25 \%$ of the plot area. (16) This created a new archetype: the generic wedding cake, predefined by law, with the addition of an iconic tower, the apex of which, in the manner of bride and groom figures, was monumentalised to differentiate it from others. This was an archetype that all Manhattan architects responded to in the same manner. (Fig. 6) The body of the building is identical in all cases -a wedding cake that homogenised the city-, but the head, a metaphor for the apex, was where singularity was found, degenerating into a fierce competition to create the metropolitan icon. The building-heads were the bride and groom, presiding on top of the wedding cake. Everyone wanted to be part of the New York skyline, through their 'building-cakes'. 
calles al cielo y que generan una forma a la que todos los arquitectos -subyugados a los promotores- se acabarán aproximando con sus diseños con el fin de optimizar la rentabilidad de la construcción: se talla el volumen sugerido de lo que se convertirá en el prototipo de rascacielos-monumento manhattaniano, la tarta nupcial, caracterizada por el apilamiento de cuerpos cada vez de menor superficie como si de los pisos de una tarta de boda se tratara. Producto de la Ley de Zonificación de 1916, el volumen máximo queda definido por una envolvente piramidal a la que los promotores tratarán de aproximarse para no perder ni un milímetro de suelo disponible: gracias al acero, se cubica su masa permitiendo espacios habitables rectangulares más convencionales así como se ejecuta una construcción más económica. (15) (Fig. 5)

Pero, paradójicamente, y a pesar del aparente control sobre el volumen edificado, la Ley realiza una excepción, legitimando la batalla del rascacielosicono en un $25 \%$ de la superficie del solar: (16) se autoriza la construcción de una torre de altura indefinida. Se perfila aquí la coronación del nuevo arquetipo: la tarta nupcial, genérica y predefinida por la Ley, a la que se le anexiona la torre-icono, cuya cúspide, a modo de figuras de novios, se monumentaliza para diferenciarse de las demás. Un arquetipo que viste a los arquitectos de Manhattan respondiendo al mismo patrón; (Fig. 6) el torso es idéntico en todos los casos: una tarta nupcial que homogeneiza la ciudad; es en la cabeza, metáfora de la cúspide, en donde se instalará la singularidad, degenerando en una encarnizada competición por convertirse en el icono metropolitano. Sus edificios-cabeza serán los novios que presiden la tarta de boda. Todos desean figurar en el skyline de Nueva York a través de sus 'edificios-tarta'.

Muy pronto se convertirá en una tipología exitosa, rápidamente replicada en otros países. Como nos cuenta Rem Koolhaas en relación con el concurso del Palacio de los Soviets en Moscú, del año 1935, (Fig. 7) se premia al rascacielos-pastiche, listo para expandirse más allá de las fronteras: Lenin como la abstracción de los novios que coronan la tarta nupcial. (17)

Very soon this typology became successful, and was rapidly copied in other countries. As Rem Koolhaas stated in relation to the Moscow Palace of the Soviets competition, in 1935, (Fig. 7) the pastiche-skyscraper won. It was ready for its expansion across borders: Lenin as an abstraction of the wedding couple that crowns the wedding cake. (17) It was the wedding cake that Gordon Matta-Clark had already attacked with the photos illustrating the Anarchitecture group's interests. (Fig. 8) One of these photos clearly shows a wedding cake cut by Gordon, trying to destabilise the skyscraper as a symbol of metropolitan prosperity, with the words: "NOT MAKE BAKE".

Once again, the sword of Damocles represents the deep crack that fractures the skyscraper, a fragment of a metropolis that develops a non-existent language. As Diana Agrest explains in Oppositions, (18) Manhattan acts as an explosion of meaning and design that leaves architecture in a profound crisis; skyscrapers are the scattered fragments of that explosion.

Rem Koolhaas used the same sword to deal death to skyscrapers as an obsolete typology, (Fig. 9) ironically commenting that the skyscraper culture is an ideology in expansion that, rather than learning its lesson, celebrates its success when it should have gone out of style. Regarding his projects at the end of the 20th century (19) in Asia, he employed the image of the Jin Mao Tower - part of the Shanghai World Financial Centre- to reflect on an already worn out typology, now exhausted and without having evolved during its near century of life since the dawn of the 19th century. Through his proposal for the Beijing CBD Core, (20) Koolhaas prosed a new way to organise the 'urban substance' that avoids the 'skyscraper forest'. (21) For Rem Koolhaas, "The skyscraper is a bizarre typology. Almost perfect at its inven- 
Una tarta de boda contra la que Gordon Matta-Clark ya había arremetido anteriormente a través de las fotografías que ilustran los intereses del grupo Anarchitecture. (Fig. 8) En una de ellas se muestra claramente una tarta nupcial que Gordon atraviesa con uno de sus cortes tratando de desestabilizar el rascacielos como símbolo de la prosperidad de la urbe, anotando lo siguiente: "NOT MAKE BAKE". Una vez más, la espada de Damocles que representa la profunda grieta que fractura el rascacielos, fragmento de una metrópolis que desarrolla un lenguaje inexistente. Como explica Dia-
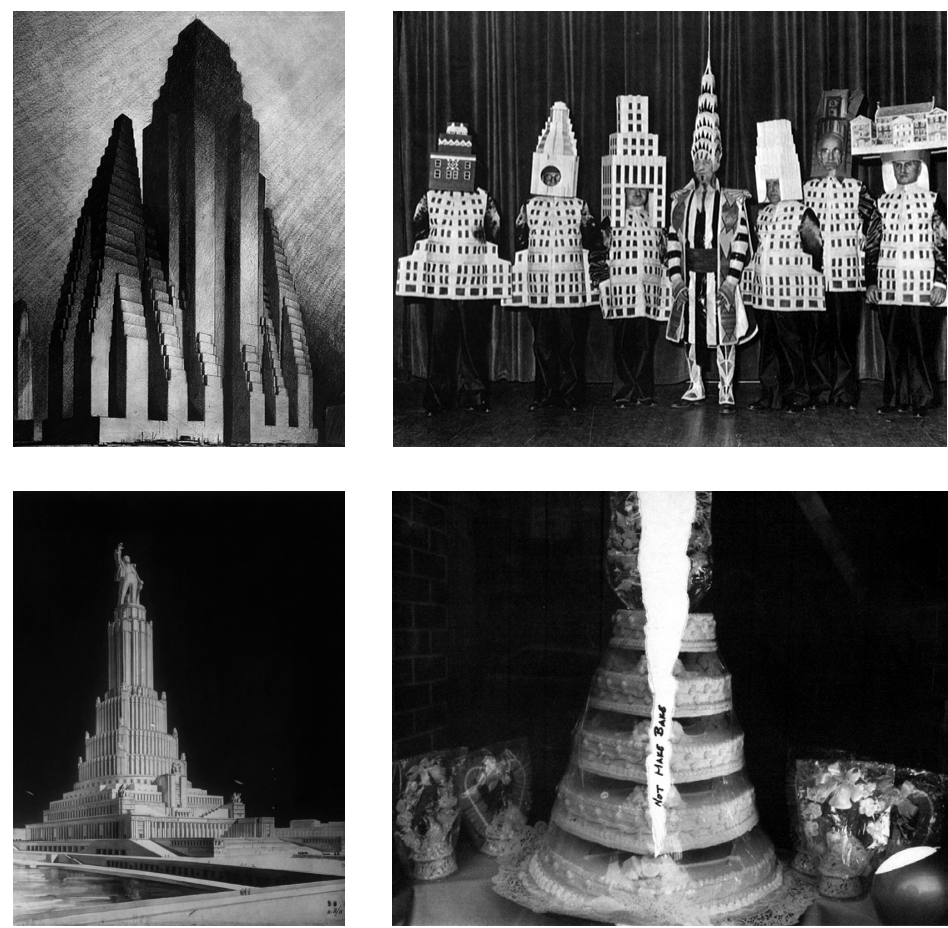

Fig. 5. Ferriss, Hugh. The Metropolis of Tomorrow, 1929. La confirmación del estilo 'wedding cake'.

Fig. 6. Imagen del baile de disfraces celebrado el 23 de enero de 1931 bajo el título Fête moder$n e$ en el hotel Astor de Manhattan. Incluida en Koolhaas, Rem. Delirious New York: a retroactive manifesto for Manhattan, 1978.

Fig. 7. Fotografía de perspectiva de Boris Iofan: concurso del Palacio de los Soviets de Moscú, (febrero 1935). Colección CCA, Montreal [PH1998:0026:007].

Fig. 8. Matta-Clark, Gordon. Sin Título, (Anarquitectura), 1974. Archivo CCA, Montreal [PHCON2003:0016:0006:027]. El corte de la tarta nupcial, metáfora de la criris del rascacielos de Manhattan.

tion -and more than any other more evolutionary type, it is an invention- the skyscraper has become less interesting in inverse proportion to its success". (22)

This is a reflection of the corrupt situation that the skyscraper monumentalises, transforming it into a thermometer of economic power -the prosperity of a city is directly proportional to the height of its financial district- a subject that leads Rem Koolhaas to ask: how long will skyscrapers continue be a symbol of business? Why are skyscrapers the preferred shape? According to Rem Koolhaas, that convention should remind us of the role of the architect in this field: the battle between external forces -bureaucracy, speculation, economic viability, metropolitan icon-and the internal forces -the place of the architects' creativity-. The battle ends up destabilising the fundamental pillars of the iconic-skyscraper. The wedding cake collapses as a product of speculation, private initiative, and fruit of the design of the large firms that are subject to the new creed that governs cities, but do not use their creativity to prevent it from happening. (23) (Fig. 10) To summarise, says Koolhaas, "architecture is a poisonous mix of power and impotence". (24) The architect and his client crown the wedding cake in a relationship vitiated by dominance and indifference that, subtly, turns stormy, causing the wedding cake to collapse as the model structure that colonises and metropolises' financial districts. The time has come to find new shapes that move away from the premise "form follows speculation".

It is from this poisonous mixture of equal portions of power and impotence that the skyscraper derives its strength. However, Gordon Matta-Clark's proposal is very clear: make a deep cut into the monolith, causing it to destabilise and later 
na Agrest en Oppositions, (18) Manhattan funciona como una explosión de significado y diseño que coloca a la arquitectura en una profunda crisis; los rascacielos son fragmentos diseminados por semejante explosión.

La misma espada es la que emplea Rem Koolhaas para dar muerte al rascacielos como tipología obsoleta, (Fig. 9) ironizando con la cultura del rascacielos como ideología en expansión la cual, lejos de haber aprendido la lección, celebra su éxito cuando en realidad debería estar desfasada. A colación de sus proyectos en Asia con los que cierra el siglo xx, (19) emplea la imagen de la Jin Mao Tower -ubicada en World Financial Center de Shanghái- para reflejar una tipología ya exhausta, demasiado exprimida y sin haber evolucionado en casi un siglo de vida en los albores de siglo xxi.Mediante la propuesta Beijing CBD Core, (20) Koolhaas propone una nueva manera de organizar la 'sustancia urbana' que no sea mediante un 'bosque de rascacielos' (21) Para Rem Koolhaas, "El rascacielos es una tipología extravagante. Casi perfecto en su concepción -y más que cualquier otra tipología evolutiva, es una invención- el rascacielos se ha vuelto menos interesante en proporción inversa a su éxito". (22)

Un reflejo de la situación viciada que monumentaliza el rascacielos transformándolo en un termómetro del poder económico -la prosperidad de la ciudad es directamente proporcional a la altura de su distrito financiero- tema que se cuestiona Rem Koolhaas. ¿Cuánto tiempo se mantendrá el rascacielos como el símbolo de los negocios? ¿Por qué es el rascacielos su forma preferida? Según Rem Koolhaas, tal convención viene a recordarnos el papel del arquitecto dentro de semejante empresa: una batalla entre las fuerzas externas -burocracia, especulación, viabilidad económica, icono metropolitano- y las fuerzas internas -el lugar para la creatividad del arquitecto- que acaba por desestabilizar los pilares fundamentales del rascacielos-icono: la tarta nupcial se desmorona como producto de la especulación, de iniciativa privada, y fruto del diseño de las grandes firmas sometidas al nuevo credo que gobierna las ciudades, las cuales no hacen nada por evitarlo desde el lado de la creatividad. (23) (Fig. 10) En resumen, nos dice Koolhaas: "La arquitectura es una mezcla venenosa de poder e impotencia”. (24) El arquitecto y su cliente coronan la

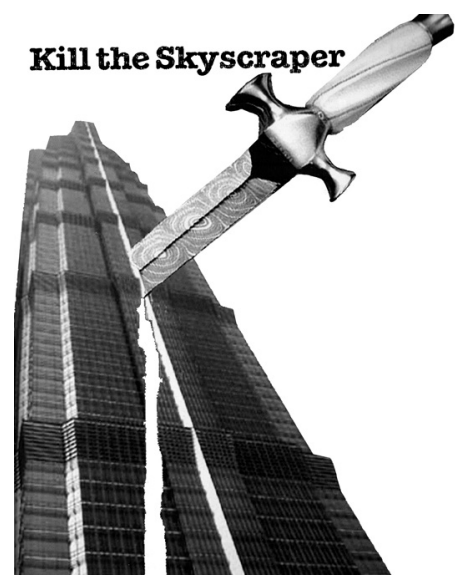

Fig. 9. Koolhaas, Rem: Content, 2004, p. 473. Fig. 10. Koolhaas, Rem. Content, 2004, p. 64.

collapse. "Making the right" (cut), delivering a well-aimed blow that destabilises the rigidity of the structure camouflaged as a monument merely because of its great magnitude. (Fig. 11)

With the same force that he makes his building cuts, Matta-Clark imagines a metaphorical cut that dismembers the skyscraper as a unit, causing its structure to collapse. To what end? It has a direct objective: to erase all vestiges of high buildings so that the horizon can be completely free of those urban masses. (Fig. 12) It is not a coincidence that Gordon Matta-Clark eradicate their presence in the landscape. In the original text he underlined "the perfect structure". The absence of those unwanted volumes is, in some ways, a premonition of what would years later occur on 11th of September: the disaster that delivered a hard blow to the architectural emblem of Manhattan, making not just one, but two of the Twin Towers collapse.

This was an episode in the history of skyscrapers that would not go unnoticed by Rem Koolhaas, who agreed with Gordon Matta-Clark's arguments. For him, the World Trade Center synthesised the exhaustion of skyscrapers as a type: the towers dominate Manhattan's horizon but do not really participate in it -twinning is their only genius-. (25)

"Major architecture firms are prolonging the life of a type that has not been invested with new thinking or ambition since the World Trade Center's completion in 1972. Having made New York City an unbearable demonstration of architectural mediocrity, they continue their mission on a new continent". (26) 
tarta nupcial en una relación viciada de dominio e indiferencia que, súbitamente, se torna tormentosaprovocando el derrumbe de la tarta nupcial como estructura modelo que coloniza los distritos financieros de las metrópolis. Ha llegado el momento de encontrar nuevas formas que se alejen de la premisa "la forma sigue a la especulación".

$Y$ en esa mezcla envenenada de poder e impotencia a partes iguales es donde el rascacielos se hace fuerte. Pero la propuesta de Gordon Matta-Clark es muy clara: realizar un profundo corte al monolito provocando su desestabilización y posterior colapso. "Hacer lo correcto" asestando ese golpe certero que desestabiliza la rigidez de la estructura camuflada de monumentalidad por su sola envergadura. (Fig. 11)

Con la misma rotundidad con la que plantea sus building cuts, Matta-Clark se imagina un corte metafórico que desmembra el rascacielos como unidad, logrando así el colapso de su estructura. ¿Con qué fin? Con un objetivo directo: borrar todo vestigio de edificación en altura para alcanzar un horizonte completamente despejado de semejantes masas urbanas. (Fig. 12) No por casualidad Gordon Matta-Clark tachará su presencia en el paisaje. Subrayado en el texto original, "la estructura perfecta". La ausencia de tales volúmenes indeseados es en cierto modo una premonición de lo que acontecerá años más tarde un 11 de septiembre: el desastre asesta un duro golpe al emblema arquitectónico de Manhattan haciendo colapsar no una sino las dos Torres Gemelas.

Un episodio en la historia del rascacielos que no pasará desapercibido tampoco para Rem Koolhaas, que secundará los argumentos de Gordon MattaClark. Para él, el World Trade Center sintetiza el agotamiento del rascacielos como tipología: las torres dominan el horizonte de Manhattan pero no participan realmente en él -el hermanamiento es su única genialidad-. (25)

"Las principales firmas de arquitectura están prolongando la vida de un tipo al que no se le han aportado nuevas ideas o ambiciones desde la finalización del World Trade Center en 1972. Después de que Nueva York hiciera una

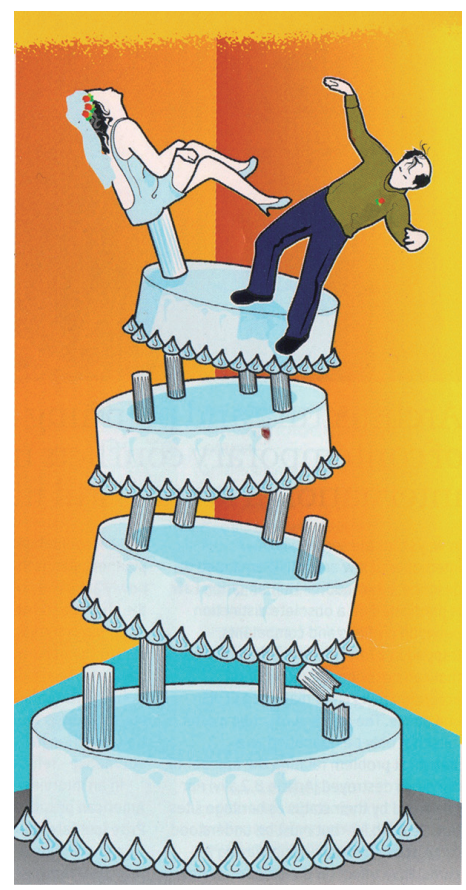

The perpetuation of the other Koolhaasian ideology can be summarised thus: an ironic homage to the consequences of the incorrect interpretation of the Miesian quote "less is more". The architecture of 1970's thus reached the zero degree, stripped of all specific characteristics, entering into a tragic period of illiteracy, a "semantic nightmare". An architecture reduced to a box of steel and glass. For this reason, Rem Koolhaas found another opportunity in the disaster: to not be victims of the amnesia that makes us commit the same errors over and over again.

"9/11: From now on, the most important city in the world is dominated by the tower from which once dangled an ape [...] New Yorkers surrender to empathy. The tragedy of $9 / 11$ inspires a mood of collective tenderness that is almost exhilarating, almost a relief: hype's spell has been broken and the city can recover its own reality principle, emerge with new thinking from the unthinkable". (27)

Finish through removal: cultivate the void, proclaiming an absence whose remains echo with what was once there but is no longer. Rem Koolhaas makes the same simile, comparing the Temple of the Philistines with the attacks on 9/11. At the end of Samson's life, as narrated in the Bible -Book of Judges 16:23-30- Samson broke two of the temple's columns, so destroying it. Beside it, he puts an image of the World Trade Center after its destruction and ensuing state of ruin. (Fig. 13)

Koolhaas' interpretation of the Palace of the Soviets in $S M L X L$ is a summary of everything analysed up to this point: instead of a solid, the building -the construction of which was cancelled after only the foundations had been built- becomes a void, an absence. Its foundation was formed into a swimming pool, the steam from which, on days with little wind, 
manifestación insoportable de la mediocridad arquitectónica, continúan su misión en un nuevo continente". (26)

Se consolida así la perpetuación de otra ideología koolhaasiana: un irónico homenaje a las consecuencias de la errónea interpretación del "menos es más" miesiano. La arquitectura de los setenta alcanza así el grado cero, despojada de toda especificidad, entrando en un trágico periodo de analfabetismo, una "pesadilla semántica". Una arquitectura reducida a la caja de acero y vidrio. Por lo que Rem Koolhaas verá una vez más en el desastre la ocasión para no ser víctimas de la amnesia que nos hace cometer los mismos errores.

“9/11: A partir de ahora, la ciudad más importante del mundo está dominada por la torre de la que una vez se colgaba un mono [...] Los neoyorquinos se rinden a la empatía. La tragedia inspira un sentimiento de ternura colectiva que es casi estimulante, casi un alivio: el hechizo del despliegue publicitario se ha roto y la ciudad puede recuperar su propio principio de realidad, emergiendo con un nuevo pensamiento a partir de lo inimaginable". (27)

Finalizar eliminando: cultivar el vacío proclamando una ausencia cuyos vestigios se hacen eco de lo que en algún momento fue pero dejó de ser. Así Rem Koolhaas establece el mismo símil, comparando el templo de los filisteos con los atentados del 11-S. Mediante el fin de la historia de Sansón, narrada en la Biblia -Libro de los Jueces 16:23-30- Sansón derrumba el templo asestando un golpe certero entre dos columnas y provocando así su destrucción. A su lado, una imagen del World Trade Center tras su derrumbe y posterior estado de ruina. (Fig. 13)

La interpretación que hace Koolhaas del Palacio de los Soviets en S M L XL resume lo hasta ahora analizado: en vez de un sólido, el edificio -cuya construcción queda cancelada con la cimentación realizada- se convierte en vacío, en ausencia. Su cimentación es declarada piscina, cuyo vapor, en los días de poco viento, reconstruye un edificio virtual de mayor potencia si cabe que la
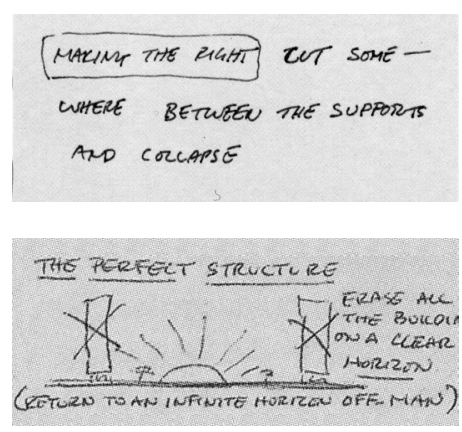

Fig. 11. Matta-Clark, Gordon. Art Card, 1973. Nota manuscrita. Archivo CCA, Montreal [PHCON2002:0016:001:030.7]. "Practicando el corte certero en algún lugar entre los soportes y colapso".

Fig. 12. Matta-Clark, Gordon. Proyectos para anarquitectura, 1973. "La estructura perfecta. Borrar toda la edificación sobre un horizonte despejado. (Retorno a un horizonte infinito sin el hombre)".

reconstructs a virtual building of greater power than if the wedding cake had been built... (28) The absence is transformed into the most powerful form of presence...

An absence transformed into the greatest expression of virtual presence, and that evolves into the true meaning of monumentality that moves them both: the void is the true material. The image that Gordon Matta-Clark included in the Anarchitecture exhibition is illuminating: (Fig. 14) it is not the Twin Towers, but the space between them that is the true monument to absence, as if with a deep cut the intermediate space is transformed into a monumentalised virtual reality by the transfer of identity. Gordon Matta-Clark was fascinated by the monument to void implied by the area between the towers: a non-constructed space that Gordon Matta-Clark recognises and catalogues as the significant element of the World Trade Center. As Diana Angrest concluded, (29) the monolith-skyscraper splits into two twin entities, where the crown as a symbol is replaced by two key aspects: its parity and the space between the towers, considered to be a form in its own right, and ultimately, presence.

This did not go unnoticed by Rem Koolhaas, who, in an ironic act, transforms the skyscraper into a monument to absence: the proposal for CCTV in China is an experiment on the obsolete typology of skyscrapers. The tower is transformed and parity disappears by simply creating a continuous loop, which folds over itself and embraces a space, a space that before was in the middle, but is now central. The void is monumentalised and absence has been transformed into significant presence. (Fig. 13) As Diana Agrest also noted, the space between the World Trade Center towers acts as a virtual door between the field of architecture and the kingdom of non-architecture, between presence and absence, something that is permanently depicted in the CCTV design. Its monumentality is not based on height as an inherent quality of skyscrapers, but on void as the most effective form of presence... 
wedding cake que sustituye y que no llegó a ser... (28) La ausencia se transforma en la más potente forma de presencia...

Una ausencia transformada en la máxima expresión de presencia virtual que deviene en el verdadero sentido de monumentalidad que mueve a ambos: el vacío es la verdadera materia. La imagen que Gordon Matta Clark incluye en la exposición de Anarchitecture es esclarecedora: (Fig. 14) no son las Torres Gemelas sino el espacio entre ellas el verdadero monumento a la ausencia. Como si de un profundo corte se tratara, el espacio intermedio se transforma en una realidad virtual monumentalizada por transferencia de identidad. Y es que Gordon Matta-Clark se siente verdaderamente fascinado por el monumento al vacío que implica el área entre torres: un espacio no construido que Gordon Matta-Clark reconoce y cataloga como el elemento significante del World Trade Center. Tal y como concluye Diana Agrest, (29) el rascacielosmonolito se desdobla en dos entidades gemelas, en donde la coronación como símbolo es metonímicamente reemplazada por dos aspectos clave: la condición de paridad y el espacio entre las torres que es considerado forma en sí mismo y, en definitiva, presencia.

Algo que tampoco pasaría desapercibido para Rem Koolhaas, el cual, en un acto de ironía, transforma el rascacielos en un monumento a la ausencia: la propuesta del CCTV en China sirve de experimentación sobre la tipología obsoleta de rascacielos. La torre se transforma haciendo desaparecer la paridad mediante una sencilla operación de bucle continuo, plegándose sobre sí misma y abrazando un espacio, antes intermedio, que ahora es central: el vacío se monumentaliza transformando la ausencia en presencia significante. (Fig. 13) Algo que también Diana Agrest puntualiza, y es que el espacio entre las torres del World Trade Center actúa de puerta virtual entre el campo de la arquitectura y el reino de la no-arquitectura, entre la presencia y la ausencia, algo que queda definitivamente retratado en el proyecto del CCTV. Su monumentalidad no radica en la altura como cualidad inherente al rascacielos sino en el vacío como la más eficaz forma de presencia...

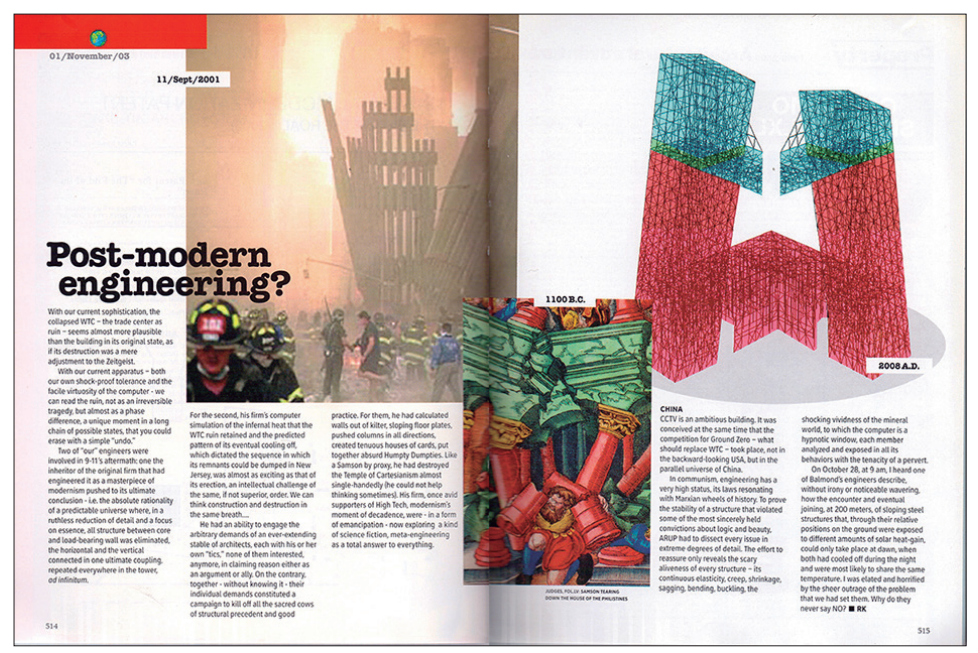

Fig. 13. Koolhaas, Rem: "Post-modern engineering”. Content, 2004. 514-515 pp. Tres fechas cruciales: el templo de los filisteos, los atentados del 11S y la propuesta para el CCTV de China.

Fig. 14. Matta-Clark, Gordon. "View of the Twin Towers of the World Trade Center, New York City, New York, 1974". Archivo CCA, Montreal [PH2002:0049].

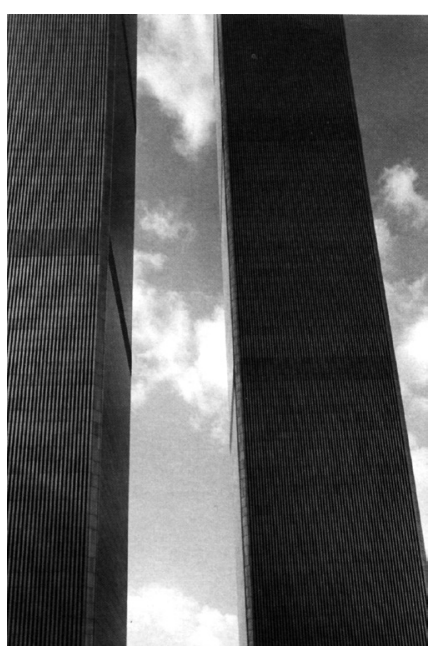




\section{NOTAS}

1. Definición de 'anti-monumento', Gordon Matta-Clark. Texto extraído de MATTA-CLARK, Gordon. 'Letter from Gordon MattaClark to the Meeting (10 December 1973)'. Archivo CCA, Montreal [PHCON2002:0016:001:043]. El texto en mayúsculas, así como los posibles subrayados o tachados, se corresponden con los manuscritos originales de Gordon Matta-Clark, por lo que se transcribe literalmente en todas las citas aquí reproducidas.

2. Definición de 'automonument' de Rem Koolhaas, cuya acepción aparece en el diccionario de KOOLHAAS, Rem; MAU, Bruce. SMLXL. Nueva York: Monacelli Press,1995. 32 p., y que es a su vez un extracto de KOOLHAAS, Rem. Delirious New York: a retroactive manifesto for Manhattan. Nueva York: Oxford University Press, 1978.

3. Gordon Matta-Clark se graduaría en la universidad de Cornell en el año 1968 regresando posteriormente a la isla de Manhattan e instalándose finalmente en el barrio del Soho, que por aquel entonces se estaba transformando en alojamiento alternativo de artistas que habitaban sus edificaciones industriales abandonadas como espacios multifuncionales. Desde aquí Gordon desarrollaría la mayor parte de su obra. En 1971 abriría el restaurante Food, y en 1973 fundaría el grupo de pensamiento crítico Anarchitecture, desde el que desarrollaría una breve pero intensa actividad crítica.

4. En 1973 Rem Koolhaas daría el salto a la Gran Manzana de la mano del IAUS, que comenzó su andadura en 1967 como una institución de estudios independiente -bajo la dirección por aquel entonces de Peter Eisenman- donde estaría becado trabajando en Delirious New York. Tal y como lo recuerda su compañero Andrew MacNair, si bien Rem Koolhaas era miembro del Instituto, no hacía nada por la comunidad, sino que se encontraba muy centrado en su trabajo individual que forjaría el texto posteriormente publicado, si bien su investigación estaba bajo las premisas del IAUS. En FRANK, Suzanne. 2010. 260 p.

5. El detonante que da origen a la dialéctica entre Gordon Matta-Clark y Rem Koolhaas se encuentra en la entrevista que realiza John Rajchman a Rem Koolhaas, 'Thinking big - Dutch architect Rem Koolhaas - Interview', Artforum International, vol. 33, n. 4. Diciembre, 1994 y que da pie a la tesis doctoral en curso. Muchas son la lecturas que se han hecho sobre Gordon Matta-Clark como artista destructor, pero pocas apreciaciones como la que muestra Rem Koolhaas en esta entrevista aportan una visión de Gordon Matta-Clark como arquitecto del vacío, de la ausencia, cualidad que aparece de forma recurrente en la obra del propio Rem Koolhaas. Tal y como comenta en la entrevista, "Yo estaba fascinado con Gordon Mata-Clark. [...] Ahora, también creo que su trabajo era un ejemplo prematuro y riguroso de una especie de poder de la ausencia, del vacío, de la eliminación, es decir, de adición y creación".

6. LEE, Pamela M. 2000. 109 p.

7. El discurso optimista del rascacielos neoyorquino ocultaba las devastadoras consecuencias de semejante proceso de transformación. En la década de los setenta se cuentan por cientos de miles las personas que se vieron obligadas a abandonar sus casas o se quedaron sin puestos de trabajo. Las fabricas e industrias desaparecen progresivamente del centro y el número de sin techo crece exponencialmente. El panorama era desolador al tiempo que se erigía el World Trade Center como símbolo del nuevo capitalismo globalizante. En CANDELA, Iria. 2007. 18 p.

8. Gordon Matta-Clark fue invitado, junto con otros 26 artistas como Richard Serra o Vito Acconci, y bajo la iniciativa de Willoughby Sharp, a realizar una performançe ante la cámara de Harry Shunk. El lugar elegido fue el muelle 18, un área residual de los nuevos planes de regeneración urbana situada dando la espalda al nuevo distrito financiero, con la construcción del World Trade Center como telón de fondo ineludible. En SHUNK, 1992.

9. MATTA-CLARK, Gordon. 'Art Card', 1973. Nota manuscrita con el texto 'A pile of anything. Archivo CCA, Montreal [PHCON2002:0016:001:032.7].

10. El término correcto sería el inglés 'gentrification', que da nombre al proceso de reconversión urbana mediante el cual se induce al desplazamiento de las clases bajas de barrios deteriorados para ser reemplazados por aquellas de un mayor poder adquisitivo.

11. KOOLHAAS, Rem. Introducción de la conferencia What Architecture Can Do? en la Universidad Nacional de Singapur, el viernes 19 de junio de 2009.
NOTES

1. Definition of 'un-monument', Gordon Matta-Clark. Text from MATTA CLARK, Gordon. 'Letter from Gordon Matta-Clark to the Meeting (10 December 1973)'. CCA Archive, Montreal [PHCON2002:0016:001:043]. The text in capital letters, as well as underlined or crossed words, replicates the format from the original manuscripts of Gordon Matta-Clark, which are literally transcribed in all quotations reproduced in the article. 2. Definition of 'automonument' by Rem Koolhaas, whose meaning appears in the dictionary KOOLHAAS, Rem; MAU, Bruce. SMLXL. Monacelli Press: New York, 1995. 32 p., which is at the same time an excerpt from KOOLHAAS, Rem. Delirious New York: a retroactive manifesto for Manhattan. New York: Oxford University Press, 1978.

3. Gordon Matta-Clark graduated from Cornell University in 1968, later returning to the island of Manhattan. He finally settled in Soho, which was at that time an alternative residence of artists who inhabited the abandoned industrial buildings as multifunctional spaces. There, Gordon developed the greater part of his work. In 1971 he opened the Food restaurant, and in 1973 founded the critical thinking group Anarchitecture, with which he would carry out a brief but intense critical activity.

4. In 1973 Rem Koolhaas took the plunge and moved to the Big Apple with the help of IAUS This started on its course in 1967 as an independent study institution, then under the leadership of Peter Eisenman. Rem Koolhaas had a grant to work on Delirious New York. As fellow student Andrew MacNair remembers, although Rem Koolhaas was a member of the Institution, he did nothing for the educational community, but focused on his individual work which shaped the later published text, even though his research was under the premises of IAUS. In FRANK, Suzanne. 2010. 260 p.

5. The trigger that lead to the dialogue between Gordon Matta-Clark and Rem Koolhaas can be found in the interview by John Rajchman of Rem Koolhaas, 'Thinking big - Dutch architect Rem Koolhaas - Interview', Artforum International, vol. 33, n. 4. December 1994 which gave rise to this doctoral thesis. There has been a lot written about Gordon Matta-Clark as a destructive artist, but few appreciate how Rem Koolhaas revealed in this interview how he thought of Gordon Matta-Clark as an architect of space, of absence, a quality that would occur recurrently in Rem Koolhaas's own work. As he commented in the interview, "I was fascinated by Matta-Clark. [...] Now I also think that his work was very strong, an early illustration of the power of the absent, of the void, of elimination, i.e., of adding and making.

6. LEE, Pamela M. 2000. 109 p.

7. The optimistic discourse of New York skyscrapers hid the devastating consequences of a similar process of transformation. During the seventies hundreds of thousands of people had to leave their homes or were out of work. Factories and industries gradually disappeared from the city centre and the number of homeless people increased exponentially. The World Trade Center, a symbol of the new globalised capitalism, was constructed in these distressing circumstances. In CANDELA, Iria. $2007.18 \mathrm{p}$.

8. Gordon Matta-Clark was invited, along with 26 other artists such as Richard Serra and Vito Acconci, and under the initiative of Willoughby Sharp, to perform a performance that would be photographed by Harry Shunk. The chosen location was Pier 18, a residential area with new urban regeneration plans situated behind the new financial district. The construction work of the World Trade Center was the insensitive backdrop to the performances. In SHUNK, 1992.

9. MATTA-CLARK, Gordon. 'Art Card', 1973. Manuscript note with the text 'A pile of anything'. CCA Archive, Montreal [PHCON2002:0016:001:032.7].

10. Gentrification is the process of urban restructuring through which the working class is displaced from deteriorated neighbourhoods and replaced by people with a greater purchasing power.

11. Rem Koolhaas. Introduction to the conference What Architecture Can Do? at the National University of Singapore, Friday 19 of June 2009. 
12. "Más allá de cierta masa crítica, toda construcción se convierte en un monumento, $o$ al menos suscita esa expectativa sólo gracias a su tamaño, incluso aunque la suma o la naturaleza de las actividades concretas que alberga no merezca una expresión monumental”. En KOOLHAAS, Rem. 1978.

13. Dotado de cierta sencillez, el documento de Zoning Resolution de 1916 trata de establecer un control sobre la forma y altura de los edificios en Manhattan, estableciendo los retranqueos, y deriva en un método de composición del rascacielos. Sería modificado por una nueva Zoning Resolution en 1961 aceptando el esquema de edificio en altura moderno, que responde al esquema de la Lever House en 1952 o el Seagram Builiding en 1958, un modelo de caja vertical sin retranqueos cuyo máximo exponente es el World Trade Center. La ley concedía metros cuadrados extra si a cambio se cedía espacio libre para plazas y lugares públicos. Según explica Diana Agrest, se trata, en definitiva, de un proceso de transferencia de identidad en el que la cúspide del rascacielos evolutivamente se transforma en la torre vertical monolítica completa, eliminando cualquier composición de base, fuste y coronación. Ver figs. 37-38 en AGREST, Diana. 1977. 42-43 pp.

14. FERRISS, Hugh. 1953.

15. Si bien en The Metrópolis of Tomorrow todavía no aparece el término 'tarta nupcial', sí lo utiliza Hugh Ferriss con rotundidad en el texto 'Power in Buildings', de 1953, en donde compara la imagen trivial del mismo frente a la configuración en bloques, construyendo el debate 'Wedding Cake' vs. 'Slabs'. 16. Tal y como lo explica Rem Koolhaas, se toma como norma el Woolworth Building: "[...] una torre puede elevarse hasta una altura ilimitada tan sólo en el $25 \%$ de la superficie del solar. La última cláusula fomenta la tendencia de las construcciones singulares a conquistar la superficie más extensa posible -es decir, una manzana entera- con objeto de que ese $25 \%$ que puede elevarse como torre sea lo más grande (rentable) posible". En KOOLHAAS, Rem. 2004. 107 p. 17. "En los años treinta, los Soviets organizaron un concurso de un monumento a la Tercera Internacional; lo ganó un proyecto grotesco, en parte rascacielos americano y en parte Babel hueca. Parecía un agrandamiento insano de la clásica tarta nupcial; en la cumbre, la novia y el novio se transformaron para dar forma a un Lenin gigante, señalando -como siempre- hacia adelante". En 'Palace of the Soviets. Virtual Architecture: a Bedtime Story', en KOOLHAAS, Rem; MAU, Bruce. 1995. 823 p.

18. AGREST, Diana. 1977.26-51 pp.

19. Un reflejo de lo que Rem Koolhaas nombra como 'Go East': en Agosto de 2003 el número de rascacielos en Asia superó el de Norteamérica por primera vez. Una prueba más de la falta de reflexión en torno al edificio en altura: mientras que en el Oeste los expertos debaten la viabilidad del rascacielos tras los atentados del 11-S, en el Este el rascacielos se ha convertido en un prerrequisito de toda megalópolis. En KOOLHAAS, Rem. 2004. 470-471 pp. 20. En KOOLHAAS, Rem. 2004. 472-479 pp. Se trata del proyecto que presenta Rem Koolhaas para el Beijing Central Business District (CBD) en 2003. 21. En KOOLHAAS, Rem. 2004. 472-479 pp. El Beijing CBD espera alojar unos 300 rascacielos, síntoma de una falta de interacción, un centro de negocios modelado mediante 300 soledades en vez de una intensa red de relación y comunicación.

22. KOOLHAAS, Rem. 'Kill the Skyscraper. Beijing CBD Core'. 2004. 473 p. 23. Charles Jencks, en relación con la Freedom Tower, sucesora del World Trade Center neoyorkino, lo resume así: “The Architect, The Governor, The Developer, The Architect: The Collaboration of Opposites”. En JENCKS, Charles. 2005. 67 p.

24. Frase citada por Rem Koolhaas en una conferencia en Columbia University, en 1989, leitmotif del texto de Shumon Basar, 'The Poisonous Mixture' incluido en KOOLHAAS, Rem. 2004. 64-67 pp.

25. “1970's. [...] The towers dominate Manhattan's skyline but don't really participate in it - twinning is their only genius”. En KOOLHAAS, Rem. 'White briefs against filth. The Waning Power of New York' 2004. 237 pp. 26. KOOLHAAS, Rem. 'Kill the Skyscraper. Beijing CBD Core' 2004. 473 p. 27. KOOLHAAS, Rem. 'White briefs against filth. The Waning Power of New York'. 2004. 239 p.

28. 'Palace of the Soviets. Virtual Architecture: a Bedtime Story', en KOOLHAAS, Rem; MAU, Bruce. 1995. 822-825 pp.

29. AGREST, Diana. 1977. 43 p.
12. "Beyond a certain critical mass each structure becomes a monument, or at least raises that expectation through its size alone, even if the sum or the nature of the individual it accommodates does not deserve a monumental expression”. In KOOLHAAS, Rem. 1978.

13. In a simple way, the 1916 Zoning Resolution tried to establish control over the form and height of Manhattan buildings, establishing setbacks, resulting in a composition method for skyscrapers. It would be modified by a new Zoning Resolution in 1961, responding to the outline of the Lever House in 1952 and the Seagram Building in 1958: a vertical box without setbacks, best represented by the World Trade Center. The law conceded extra square meters in exchange for non-built space for squares and public spaces. As Diana Agrest explained, this resulted in an identity transfer process in which the apex of the skyscraper is transformed into a complete monolith vertical tower, eliminating any base, column or coronation. See figs. 37-38 en AGREST, Diana. 1977. 42-43 pp.

14. FERRISS, Hugh. 1953.

15. Although The Metropolis of Tomorrow did not mention the phrase 'wedding cake', Hugh Ferriss used it convincingly in 'Power in Buildings', 1953, where he compared the trivial image of a wedding cake with a building shaped of blocks. Thus he started the 'Wedding cake' vs. 'Slabs' debate. 16. As Rem Koolhaas explained, the Woolworth Building became the standard: “[...] a tower may then carry 25 percent of the plot area to unlimited heights. The last clause encourages the tendency of single structures to conquer the vastest possible area, i.e., a whole block, in order to make the 25 percent that can be Tower as large (profitable) as possible”. In KOOLHAAS, Rem. 2004. 107 p.

17. "In the thirties, the Soviets organised a competition for a monument to the Third International; it was won by a grotesque project, partly American skyscraper, partly hollow Babel. It looked like an insane enlargement of a classical wedding cake; on top, bride and groom morphed to form a huge Lenin, pointing -as always-forward. In 'Palace of the Soviets. Virtual Architecture: a Bedtime Story', in KOOLHAAS, Rem; MAU, Bruce. 1995.823 p.

18. AGREST, Diana. 1977. 26-51 pp.

19. A reflection that Rem Koolhaas called 'Go East': in August 2003 the number of skyscrapers in Asia overtook the number in North America for the first time. One more proof of the lack of reflection concerning high buildings: while in the West the experts debate the viability of skyscrapers after 9/11, in the East skyscrapers are now a prerequisite of every megalopolis. In KOOLHAAS, Rem. 2004. 470-471 pp.

20. In KOOLHAAS, Rem. 2004. 472-479 pp. Rem Koolhaas submitted a design for the Beijing Central Business District (CBD) in 2003.

21. In KOOLHAAS, Rem. 2004. 472-479 pp. It is expected that Beijing CBD will house some 300 skyscrapers, symptom of a lack of interaction, a business centre modelled on 300 skyscrapers rather than on an intense network of relationships and communication.

22. KOOLHAAS, Rem. 'Kill the Skyscraper. Beijing CBD Core'. 2004. 473 p. 23. Charles Jencks, in relation to the Freedom Tower, successor to the New York World Trade Center, summarised it as follows: "The Architect, The Governor, The Developer, The Architect: The Collaboration of Opposites". In JENCKS, Charles. 2005. 67 p.

24. Phase stated by Rem Koolhaas at a conference in Columbia University, in 1989, leit motif of a text by Shumon Basar 'The Poisonous Mixture' included in KOOLHAAS, Rem. 2004. 64-67 pp.

25. “1970's. [...] The towers dominate Manhattan's skyline but don't really participate in it - twinning is their only genius". KOOLHAAS, Rem. 'White briefs against filth. The Waning Power of New York' 2004. 237 pp. 26. KOOLHAAS, Rem. 'Kill the Skyscraper. Beijing CBD Core'. 2004. 473 p. 27. KOOLHAAS, Rem. 'White briefs against filth. The Waning Power of New York'. 2004. 239 p.

28. 'Palace of the Soviets. Virtual Architecture: a Bedtime Story', in

KOOLHAAS, Rem; MAU, Bruce. 1995. 822-825 pp.

29. AGREST, Diana. 1977. 43 p. 


\section{REFERENCIAS}

AGREST, Diana. 'Architectural Anagrams: The Symbolic Performance of Skyscrapers'. Oppositions, n. 11. MIT Press, 1977. 26-51 pp.

BARTHES, Roland. 'La Torre Eiffel.' La torre Eiffel. Textos sobre la imagen. Barcelona: Editorial Paidós, 2001. Comunicación, n. 124.

CANDELA, Iria. Sombras de Ciudad: Arte y Transformación en Nueva York, 1970-1990. Madrid: Alianza Editorial, 2007.

CORBEIRA, Darío. ¿Construir... o deconstruir? Textos sobre Gordon MattaClark, Salamanca: Ediciones Universidad de Salamanca, 2000.

FERRISS, Hugh. Power in Buildings: an Artist's View of Contemporary Architecture. Nueva York: Columbia University Press, 1953.

FRANK, Suzanne: The Institute of Architecture and Urban Studies. An Insider's Memoir. Bloomington: Author House, 2010.

JENCKS, Charles. The Iconic Building: the Power of Enigma. Londres: Frances Lincoln, 2005.

KOOLHAAS, Rem. Delirious New York, a retroactive manifesto for Manhattan. Londres: Thames \& Hudson, 1978. Para la edición en castellano: KOOLHAAS, Rem: Delirio de Nueva York. Barcelona: Gustavo Gili, 2004. KOOLHAAS, Rem. Content. Alemania: Taschen, 2004.

KOOLHAAS, Rem; MAU, Bruce. SMLXL. Nueva York: Monacelli Press, 1995. LEE, Pamela M. Object to be destroyed. The work of Gordon Matta-Clark. Cambridge: Massachusetts Institute of Technology, 2000.

RAJCHMAN, John. 'Thinking big - Dutch architect Rem Koolhaas - Interview'. Artforum International, vol. 33, n. 4. Diciembre, 1994.

RAJCHMAN, John. Constructions. MIT Press, 1998.

SHUNK, Harry. Harry Shunk: Projects: Pier 18. Nice: Musée d’art moderne er contemporain, 1992.

VV.AA. Gordon Matta-Clark. Barcelona: Ediciones Polígrafa, 2006. Catálogo de la exposición celebrada en el MNCARS. Madrid.

\section{REFERENCES}

AGREST, Diana. 'Architectural Anagrams: The Symbolic Performance of Skyscrapers'. Oppositions, n. 11. MIT Press, 1977. 26-51 pp.

BARTHES, Roland. 'La Torre Eiffel.' La torre Eiffel. Textos sobre la imagen. Barcelona: Editorial Paidós, 2001. Comunicación, n. 124.

CANDELA, Iria. Sombras de Ciudad: Arte y Transformación en Nueva York, 1970-1990. Madrid: Alianza Editorial, 2007.

CORBEIRA, Darío. ¿Construir... o deconstruir? Textos sobre Gordon Matta-

Clark, Salamanca: Ediciones Universidad de Salamanca, 2000.

FERRISS, Hugh. Power in Buildings: an Artist's View of Contemporary Architecture. New York: Columbia University Press, 1953.

FRANK, Suzanne: The Institute of Architecture and Urban Studies. An Insider's Memoir. Bloomington: Author House, 2010.

JENCKS, Charles. The Iconic Building: the Power of Enigma. London: Frances Lincoln, 2005.

KOOLHAAS, Rem. Delirious New York, a retroactive manifesto for Manhattan. Londres: Thames \& Hudson, 1978. For the spanish edition: KOOLHAAS, Rem: Delirio de Nueva York. Barcelona: Gustavo Gili, 2004.

KOOLHAAS, Rem. Content. Germany: Taschen, 2004.

KOOLHAAS, Rem; MAU, Bruce. SMLXL. Nueva York: Monacelli Press, 1995. LEE, Pamela M. Object to be destroyed. The work of Gordon Matta-Clark. Cambridge: Massachusetts Institute of Technology, 2000.

RAJCHMAN, John. 'Thinking big - Dutch architect Rem Koolhaas - Interview'. Artforum International, vol. 33, n. 4. December, 1994.

RAJCHMAN, John. Constructions. MIT Press, 1998.

SHUNK, Harry. Harry Shunk: Projects: Pier 18. Nice: Musée d’art moderne er contemporain, 1992.

VV.AA. Gordon Matta-Clark. Barcelona: Ediciones Polígrafa, 2006. Catalog for the exhibition that took place at MNCARS. Madrid.

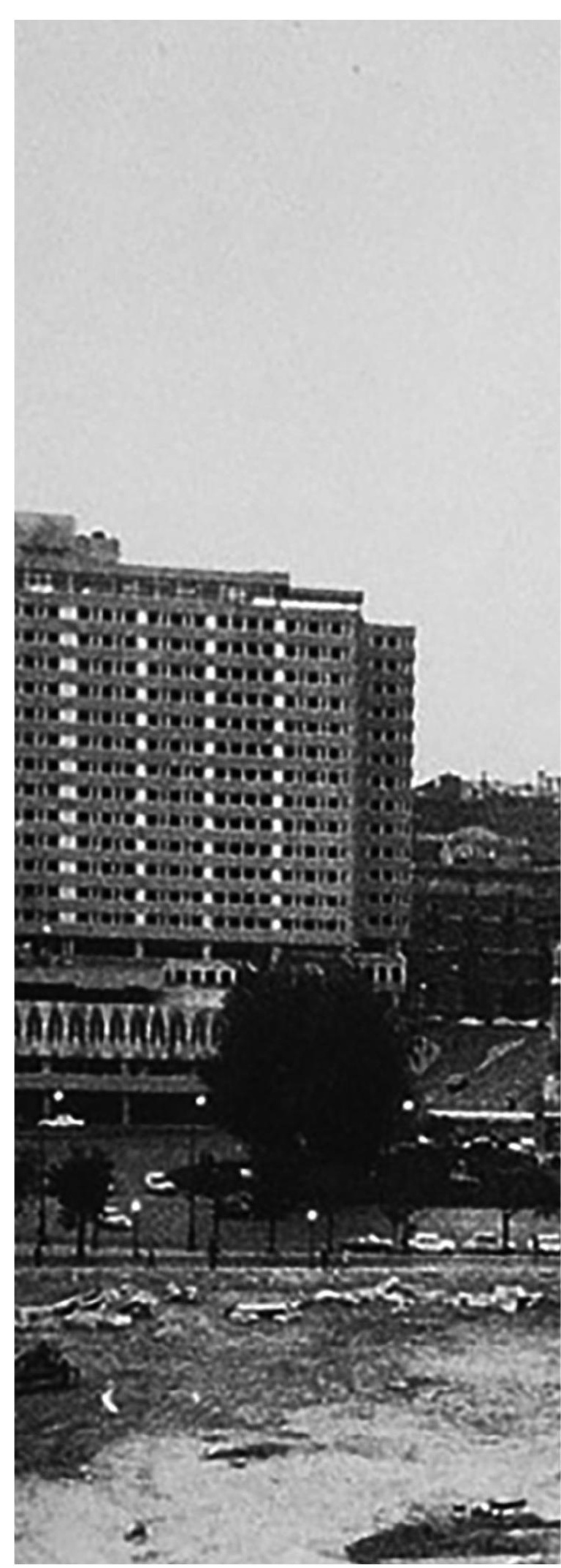

